\title{
FAKTOR YANG BERPENGARUH TERHADAP KEJADIAN POSTPARTUM BLUES
}

\author{
Devi Endah Saraswati \\ Prodi D III Kebidanan \\ STIKes Insan Cendekia Husada Bojonegoro
}

\begin{abstract}
Childbirth is a happy moment, but there are some cases can be frightening, this is because women who give birth often experience feelings of sadness and fear that affects the emotional and sensitivity of the mother, known as postpartum blues. The purpose of this study is to know the factors - factors that affect the incidence of postpartum blues.

The research design was cross sectional. The study was conducted at BPM "D" in Campurejo Village, Bojonegoro District and BPM " $S$ " in Sukorejo Village, Bojonegoro District from January to February 2018 to 30 postpartum mothers. The study instrument used an EDPS (Edinburgh Postnatal Depression Scale) questionnaire. Data processing using Chi Square test. The results showed that the factors affecting the phenotype of postpartum blues include $p$ value $=0,04$, education with $p$ value $=0,049$, obstetric status with $p$ value $=0,011$.

Factors affecting postpartum blues events include age, education, occupation, and obstetric status.
\end{abstract}

Keywords: Factors, Postpartum blues, Edinburgh Postnatal Depression Scale

Abstrak:Melahirkan adalah momen yang membahagiakan, tetapi ada beberapa kasus dapat menjadi menakutkan, hal ini disebabkan wanita yang melahirkan sering mengalami perasaan sedih dan takut sehingga mempengaruhi emosional dan sensitifitas ibu yang dikenal dengan istilah postpartumblues. Tujuan dari penelitian ini adalah unuk mengetahui faktor - faktor yang berpengaruh terhadap kejadian postpartum blues.

Desain penelitian menggunakan cross sectional. Penelitian dilakukan di BPM "D" di Desa Campurejo, Kecamatan Bojonegoro dan BPM "S" di Desa Sukorejo, Kecamatan Bojonegoro pada bulan Januari - Februari 2018 kepada 30 ibu nifas. Instrumen penelitian menggunakan kuesioner EDPS (Edinburgh Postnatal Depression Scale). Pengolahan datamenggunakan uji Chi Square. Hasil penelitian menunjukkan bahwa faktor - fakrot yang berpengaruh terhadap kejadian postpartum blues meliputi umur sengan nilai $p$ value $=0,04$, pendidikan dengan nilai $p$ value $=0,049$, status obstetrik dengan nilai $p$ value $=0,011$.

Faktor - faktor yang mempengaruhi kejadian postpartum blues meliputi umur, pendidikan, pekerjaan, dan status obstetrik.

\section{Kata Kunci : Faktor, Postpartum blues, Edinburgh Postnatal Depression Scale}

\section{PENDAHULUAN}

Prioritas pembangunan kesehatan di Indonesia adalah perbaikan kesehatan ibu dan bayi, salah satu faktor kesehatan ibu tersebut dapat dilihat dari kesehatan reproduksi. Berbagai upaya telah dilakukan oleh pemerintah untuk mencapai derajat kesehatan ibu dan bayi yang optimum seperti yang dicanangkan dalam paradigma sehat 2013 yaitu 
mengutamakan kegiatan promotif dan preventif yang mendukung upaya kuratif dan rehabilitatif (Depkes, 2005).

Sebagian besar kaum wanita menganggap bahwa kehamilan adalah peristiwa kodrati yang harus dilalui tetapi sebagian wanita menganggap sebagai peristiwa khusus yang sangat menentukan kehidupan selanjutnya (Iskandar, 2007). Melahirkan adalah sebuah karunia terbesar bagi wanita dan momen yang sangat membahagiakan, tapi ada beberapa kasus dapat menjadi momen yang menakutkan, hal ini disebabkan pada wanita yang melahirkan sering mengalami perasaan sedih dan takut sehingga mempengaruhi emosional dan sensitifitas ibu yang dikenal dengan istilah postpartumblues (Rahmawati, 2009). Postpartum blues merupakan kesedihan atau kemurungan setelah melahirkan, biasanya hanya muncul sementara waktu, yakni sekitar dua hari hingga dua minggu sejak kelahiran bayi (Dahro, 2012).

Secara global diperkirakan 20\% wanita melahirkan menderita postpartum blues. Diperkirakan $50-70 \%$ ibu melahirkan menunjukkan gejalagejala awal kemunculan postpartum blues. Di Asia angka kejadian postpartum blues cukup tinggi dan sangat bervariasi antara 26-85\% (Fatma, 2012). Angka kejadian postpartum blues di luar negeri mencapai $26-85 \%$, suatu penelitian di Negara yang pernah di lakukan seperti di Swedia, Australia, Italia dan Indononesia dengan menggunakan EDPS (Edinburg Postnatal DepressiobScale) tahun 1993 menunjukkan $73 \%$ wanita mengalami postpartum blues (Munawaroh, 2008). Menurut Santoso (2009) 50\% ibu-ibu di Indonesia menderita syndrome baby blues setelah melahirkan anaknya, sementara itu menurut Journal medika tahun 2009 di Indonesia saat ini terdapat hampir $80 \%$ ibu mengalami depresi pasca bersalin dan $75 \%$ diantaranya terjadi pada ibu primigravida. Namun hasil penelitian yang dilakukan di DKI Jakarta oleh dr. Irawati Sp.Kj menunjukkan $25 \%$ dari 580 ibu yang menjadi respondennya mengalami sindroma ini. Dan dari beberapa penelitian yang telah dilakukan di Jakarta, Yogyakarta dan Surabaya, ditemukan bahwa angka kejadiannya 11$30 \%$, suatu jumlah yang tidak sedikit dan tidak mungkin dibiarkan begitu saja (Sylvia, 2006).

Periode kehamilan dan melahirkan merupakan periode kehidupan yang penuh dengan potensi stres. Seorang wanita dalam periode kehamilan dan periode melahirkan (Postpartum) cenderung mengalami stres yang cukup besarkarena keterbatasan kondisi fisik yang membuatnya harus membatasi aktivitas. Secara psikologis seorang ibu postpartum akan melalui proses adaptasi psikologi semasa post partum (Sarwono, 2005).

Beberapa dugaan postpartum blues disebabkan oleh beberapa faktor dari dalam dan luar individu. Salah satu faktor penyebab dari dalam individu adalah adanya perubahan hormonal (Gondo, 2012). Selama kehamilan, kadar estrogen dan progesteron meningkat akibat dari plasenta yang memproduksi hormon tersebut. Akibat dari kelahiran plasenta saat persalinan, kadar estrogen dan progesteron menurun tajam mencapai kadar sebelum kehamilan dimulai pada hari ke-5 postpartum. Selain perubahan hormonal, jenis persalinan merupakan salah satu faktor penyebab dari luar individu terhadap terjadinya postpartum blues. Penelitian dari Dirksen dan Andriansen (1985, dalam Dewi, Mariati \& Wahyuni, 2011) menunjukkan bahwa beberapa teknologi medis (penggunaan alat-alat obstetric seperti caesarea, episiotomi) 
dalam pertolongan melahirkan dapat memicu postpartum blues.

Postpartum blues juga dapat disebabkan oleh faktorfisik yang disebabkan karena kelelahan fisik dalam aktivitas mengasuh bayi, menyusui, memandikan, mengganti popok, dan faktor sosial meliputi sosial ekonomi, tingkat pendidikan, status perkawinan (Nirwana, 2011). Postpartum blues terjadi karena kurangnya dukungan terhadap penyesuaian yang dibutuhkan oleh wanita dalam menghadapi aktifitas dan peran barunya sebagai ibu setelah melahirkan (Iskandar, 2007).

Ibu postpartum blues harus ditangani secara adekuat, karena peran ibu sangat berpengaruh terhadap perkembangan anak juga dalam hubungannya dengan peran ibu di keluarga. Untuk itu seorang ibu yang berada dalam kondisi pasca melahirkan perlu mendapat dukungan dari orang-orang yang ada disekitarnya. Wanita yang kurang mendapatkan dukungan sosial tentunya akan lebih mudah merasa dirinya tidak berharga dan kurang diperhatikan oleh suami maupun keluarga, sehingga wanita yang kurang mendapat dukungan sosial pada masa postpartum lebih mudah untuk mengalami depresi (Urbayatun, 2012). Peningkatan dukungan mental atau dukungan keluarga sangat di perlukan dalam mengatasi gangguan psikologis yang berhubungan dengan masa nifas ini (Dahro, 2012). Dalam menjalankan peran bidan sebagai pendidik untuk meningkatkan pengetahuan ibu tentang postpartumblues dengan memberikan informasi melalui penyuluhanpenyuluhan agar ibu-ibu pasca melahirkan yang mengalami gangguan psikologis pasca melahirkan tidak jatuh pada gangguan jiwa (Iskandar, 2007).

Di Indonesia masih belum banyak diketahui angka kejadian, mengingat belum adanya lembaga terkait yang melakukan penelitian terhadap kasus tersebut. Menurut Ade (2011) di Indonesia angka kejadian postpartum blues antara $50-70 \%$ dari wanita pasca persalinan. Secara tidak kita sadari ternyata gangguan ini mulai menunjukkan presentase yang cukup besar, penelitian yang dilakukan pun masih jarang, sehingga perlu dilakukan penelitian-penelitian yang berkaitan dengan post partum blues. Berdasarkan latar belakang tersebut peneliti tertarik untuk melakukan penelitian tentang "Faktor risiko yang berpengaruh terhadap kejadian postpartum blues "Tujuan dari penelitian ini adalah untukmengetahui faktor - faktor yang berpengaruh terhadap kejadian postpartum blues.

\section{METODE}

Desain penelitian menggunakan desain observasional analitik dengan pendekatan cross sectional. Penelitian Dilakukan di BPM "D" dan di BPM "N" Kabupaten Bojonegoro pada bulan Januari - Februari 2018 dengan jumlah responden sebanyak $30 \mathrm{ibu}$ nifas.Instrumen yang digunakan untuk untuk mengukur Postpartum Blues adalah dengan kuesioner Edinburgh Postnatal Depression Scale (EPDS) dan pedoman wawancara mendalam.Variabel independent dalam penelitian ini adalah umur, pendidikan, pekerjaan, status obstetrik, jenis persalinan, status kehamilan sedangkan variable dependent dalam penelitian ini adalah kejadian postpartum blues.Prosedur penelitian dengan meminta responden untuk mengisi kuesioner EPDS tentang perasaan yang dialami selam 7 hari.Pengolahan data dengan menggunakan computer program SPSS for windows versi 16.0.Analisis 
bivariate dengan menggunakan ujiChiSquare.

\section{HASIL \& PEMBAHASAN \\ a.Hasil penelitian Analisis Univariat}

1) Umur Responden

Tabel 1 : Karakteristik Umur Responden

\begin{tabular}{lcc}
\hline \multirow{2}{*}{ Umur } & \multicolumn{2}{c}{ Jumlah } \\
\cline { 2 - 3 } & $\mathrm{n}$ & $\%$ \\
\hline$<20$ tahun & 3 & 10 \\
$20-35$ tahun & 20 & 66,7 \\
$>35$ tahun & 7 & 23,3 \\
\hline Total & 30 & 100 \\
\hline
\end{tabular}

Berdasarkan tabel diatas dapat dijelaskan bahwa sebagian besar umur responden adalah $20-35$ tahun yaitu sebanyak 20 responden $(23,3 \%)$.

2) Pendidikan

Tabel 2 : Karakteristik Pendidikan Responden

\begin{tabular}{lcc}
\hline Pendidikan & \multicolumn{2}{c}{ Jumlah } \\
\cline { 2 - 3 } & $\mathrm{n}$ & $\%$ \\
\hline a. SD & 1 & 3,3 \\
b. SMP & 15 & 50 \\
c. SMA & 12 & 40 \\
d. PT & 2 & 6,7 \\
\hline Total & 30 & 100
\end{tabular}

Berdasarkan tabel diatas dapat dijelaskan bahwa sebagian besar pendidikan responden dengan pendidikan SMP yaitu sebanyak 15 responden $(50,3 \%)$.

3) Pekerjaan

Tabel 3 : Karakteristik Pekerjaan Responden

\begin{tabular}{lcc}
\hline Pekerjaan & \multicolumn{2}{c}{ Jumlah } \\
\cline { 2 - 3 } & $\mathrm{n}$ & $\%$ \\
\hline Petani & 2 & 6,7 \\
PNS & 1 & 3,3 \\
Swasta & 2 & 6,7 \\
Wiraswasta & 8 & 26,7 \\
Tidak Bekerja & 17 & 56,7 \\
\hline Total & 30 & 100 \\
\hline
\end{tabular}

Berdasarkan tabel diatas dapat dijelaskan bahwa sebagian besar pekerjaan responden adalah tidak bekerja sebanyak 56,7 responden $(56,7 \%)$.

4) Status Obstetrik

Tabel 4 : Karakteristik Status Obstetrik

\begin{tabular}{lcc}
\hline Status Obstetrik & \multicolumn{2}{c}{ Jumlah } \\
\cline { 2 - 3 } & $\mathrm{n}$ & $\%$ \\
\hline a. Primipara & 10 & 33,3 \\
b. Multipara & 20 & 66,7 \\
\hline Total & 30 & 100
\end{tabular}

Berdasarkan tabel diatas dapat dijelaskan bahwa sebagian besar responden dengan status obstetrik multipara yaitu sebanyak 20 responden $(66,7 \%)$.

5) Jenis Persalinan

Tabel5 : Karakteristik Jenis Persalinan Responden

\begin{tabular}{lcc}
\hline Jenis Persalinan & \multicolumn{2}{c}{ Jumlah } \\
\cline { 2 - 3 } & $\mathrm{n}$ & $\%$ \\
\hline Normal & 30 & 100 \\
\hline Total & 30 & 100
\end{tabular}

Berdasarkan tabel diatas dapat dijelaskan bawa seluruh responden dengan jenis persalinan normal yaitu sebanyak 30 responden (100\%).

6) Status Kehamilan

Tabel 6 : Karakteristik Status Kehamilan Responden

\begin{tabular}{lcc}
\hline \multirow{2}{*}{ Status Kehamilan } & \multicolumn{2}{c}{ Jumlah } \\
\cline { 2 - 3 } & $\mathrm{n}$ & $\%$ \\
\hline Direncanakan & 30 & 100 \\
\hline Total & 30 & 100
\end{tabular}

Berdasarkan hasil tabulasi data diatas dapat dijelaskan bahwa seluruh responden dengan status kehamilan direncanakan yaitu sebanyak 30 responden $(100 \%)$.

7) Status Pernikahan

Tabel 7 : Karakteristik Status Pernikahan Responden

\begin{tabular}{lcc}
\hline \multirow{2}{*}{ Status Pernikahan } & \multicolumn{2}{c}{ Jumlah } \\
\cline { 2 - 3 } & $\mathrm{n}$ & $\%$ \\
\hline Sah & 30 & 100 \\
\hline Total & 30 & 100 \\
\hline
\end{tabular}


Berdasarkan hasil tabulasi data diatas dapat dijelaskan bahwa seluruh responden dengan status pernikahan sah yaitu sebanyak 30 responden (100\%).

8) KejadianPostpartum Blues Tabel 8 : KejadianPostpartum Blues

Kejadian Jumlah $\%$

\begin{tabular}{lcc}
\hline Iya & 9 & 30 \\
\hline Tidak & 21 & 70 \\
\hline Total & 30 & 100
\end{tabular}

Berdasarkan hasil tabulasi data diatas dapat dijelaskan bahwa sebagian besar responden yang mengalami postpartum blues sebanyak 21 orang (70\%).

\section{Analisis Bivariat}

Analisis ini menyajikan analisis data dua variabel.

1. Umur dengan Kejadian Postpartum Blues

Tabel 8 : Hubungan Umur denganPostpartum Blues Tahun 2018

\begin{tabular}{|c|c|c|c|c|c|c|c|}
\hline \multirow{3}{*}{$\begin{array}{c}\text { Umur } \\
\text { (tahu } \\
\text { n) }\end{array}$} & \multicolumn{4}{|c|}{ Postpartum Blues } & \multirow{2}{*}{\multicolumn{2}{|c|}{ Total }} & \multirow{3}{*}{$\begin{array}{c}P \\
\text { val } \\
\text { ue }\end{array}$} \\
\hline & \multicolumn{2}{|c|}{ Iya } & \multicolumn{2}{|c|}{ Tidak } & & & \\
\hline & $\mathrm{n}$ & $\%$ & $\mathrm{n}$ & $\%$ & $\mathrm{n}$ & $\%$ & \\
\hline$<20$ & 0 & 0 & 3 & 10 & 3 & 10 & 0,0 \\
\hline $20-35$ & 9 & 30 & 11 & $\begin{array}{c}36 \\
, 7\end{array}$ & 20 & $\begin{array}{r}66 \\
, 7\end{array}$ & \\
\hline$>35$ & 0 & 0 & 7 & $\begin{array}{r}23 \\
, 3\end{array}$ & 7 & $\begin{array}{r}23 \\
, 3\end{array}$ & \\
\hline Total & 9 & 30 & 21 & 70 & 30 & $\begin{array}{c}10 \\
0\end{array}$ & \\
\hline
\end{tabular}

Dari tabel diatas dapat dijelaskan bahwa postpartum blues sebagian besar terjadi pada rentang umur 20 - 35 tahun yaitu sebanyak 9 responden $(30 \%)$ dengan nilai $p$ value $=0,04(<0,05)$ yang berati ada hubungan umur dengan kejadian postpartum blues.

2. Pendidikan dengan Kejadian Postpartum Blues

Tabel 9 : Hubungan Pendidikan denganPostpartum Blues Tahun 2018

\begin{tabular}{|c|c|c|c|c|c|c|c|}
\hline \multirow{3}{*}{$\begin{array}{l}\text { Pendi } \\
\text { dikan }\end{array}$} & \multicolumn{4}{|c|}{ Postpartum Blues } & \multirow{2}{*}{\multicolumn{2}{|c|}{ Total }} & \multirow{3}{*}{$\begin{array}{c}P \\
\text { valu } \\
e\end{array}$} \\
\hline & \multicolumn{2}{|c|}{ Iya } & \multicolumn{2}{|c|}{ Tidak } & & & \\
\hline & $\mathrm{n}$ & $\%$ & $\mathrm{n}$ & $\%$ & $\mathrm{n}$ & $\%$ & \\
\hline SD & 1 & 3,3 & 0 & 0 & 1 & $\begin{array}{l}3, \\
3\end{array}$ & $\begin{array}{c}0,04 \\
9\end{array}$ \\
\hline SMP & 7 & 23,3 & 8 & $\begin{array}{l}26 \\
, 7 \\
\end{array}$ & 15 & 50 & \\
\hline SMA & 1 & 3,3 & 11 & $\begin{array}{l}36 \\
, 7\end{array}$ & 12 & 40 & \\
\hline PT & 0 & 0 & 2 & $\begin{array}{l}6, \\
7\end{array}$ & 2 & $\begin{array}{l}6 \\
7\end{array}$ & \\
\hline Total & 9 & 30 & 21 & 70 & 30 & $\begin{array}{c}10 \\
0\end{array}$ & \\
\hline
\end{tabular}

Dari tabel diatas dapat dijelaskan bahwa postpartum blues sebagian besar terjadi pada tingkat pendidikan SMP yaitu sebanyak 7 responden $(23,3 \%)$ dengan nilai $p$ value $=0,049(<0,05)$ yang berati ada hubungan pendidikan dengan kejadian postpartum blues.

3. Pekerjaan dengan Kejadian Postpartum Blues

Tabel 4.10: Hubungan Pekerjaan dengan Postpartum Blues Tahun 2018

\begin{tabular}{|c|c|c|c|c|c|c|c|}
\hline \multirow{3}{*}{ Pekerjaan } & \multicolumn{4}{|c|}{ Postpartum Blues } & \multirow{2}{*}{\multicolumn{2}{|c|}{ Total }} & \multirow{3}{*}{$\begin{array}{c}P \\
\text { value }\end{array}$} \\
\hline & \multicolumn{2}{|c|}{ Iya } & \multicolumn{2}{|c|}{ Tidak } & & & \\
\hline & $\mathrm{n}$ & $\%$ & $\mathrm{n}$ & $\%$ & $\mathrm{n}$ & $\%$ & \\
\hline Petani & 2 & 6,7 & 0 & 0 & 2 & 6,7 & $\begin{array}{c}0,15 \\
6\end{array}$ \\
\hline PNS & 0 & 0 & 1 & 3,3 & 1 & 3,3 & \\
\hline Swasta & 1 & 3,3 & 1 & 3,3 & 2 & 6,7 & \\
\hline Wiraswasta & 1 & 3,3 & 7 & 23,3 & 8 & 26,7 & \\
\hline $\begin{array}{l}\text { Tidak } \\
\text { Bekerja }\end{array}$ & 5 & $\begin{array}{c}16, \\
7\end{array}$ & 12 & 40 & 17 & 56,7 & \\
\hline Total & 9 & 30 & 21 & 70 & 30 & 100 & \\
\hline
\end{tabular}

Dari tabel diatas dapat dijelaskan bahwa postpartum blues sebagian besar terjadi pada ibu yang tidak bekerja yaitu sebanyak 5 responden $(16,7 \%)$ dengan nilai $p$ value $=0,156(>0,05)$ yang berati tidak ada hubungan pekerjaan dengan kejadian postpartum blues.

4. Status Obstetrik dengan Kejadian Postpatum Blues 
Tabel 11 : Hubungan Status Obstetrik dengan Postpartum Blues Tahun 2018

\begin{tabular}{lcccccc}
\hline \multirow{2}{*}{ Status } & \multicolumn{3}{c}{ Postpartum Blues } & \multicolumn{2}{c}{ Total } \\
\cline { 2 - 5 } Obstetrik & \multicolumn{2}{c}{ Iya } & \multicolumn{2}{c}{ Tidak } & & \\
\cline { 2 - 6 } & $\mathrm{n}$ & $\%$ & $\mathrm{n}$ & $\%$ & $\mathrm{n}$ & $\%$ \\
\hline Primipara & 6 & 20 & 4 & 13,3 & 10 & 33,3 \\
\hline Multipara & 3 & 10 & 17 & 56,7 & 30 & 66,7 \\
\hline Total & 9 & 30 & 21 & 70 & 30 & 100
\end{tabular}

7. Status Pernikahan dengan Kejadian

vatTabel 14 : Hubungan Status Pernikahan dengan Postpartum Blues Tahun 2018

Dari tabel diatas dapat dijelaskan bahwa postpartum blues sebagian besar terjadi pada status obstetrik primipara yaitu sebanyak 6 responden $(20 \%)$ dengan nilai $p$ value $=0,011(<0,05)$ yang berati ada hubungan status obstetrik dengan kejadian postpartum blues.

5. Jenis Persalinan dengan Kejadian Postpatum Blues

Tabel 12 : Hubungan Jenis Persalinan denganPostpartum Blues Tahun 2018

\begin{tabular}{lcccccc}
\hline \multirow{2}{*}{$\begin{array}{c}\text { Jenis } \\
\text { Persalinan }\end{array}$} & \multicolumn{2}{c}{ Postpartum Blues } & \multicolumn{2}{l}{ Total } \\
\cline { 2 - 5 } & \multicolumn{2}{c}{ Iya } & \multicolumn{2}{c}{ Tidak } & & \\
\cline { 2 - 6 } Normal & 9 & 30 & 21 & 70 & 30 & 100 \\
\hline Total & 9 & 30 & 21 & 70 & 30 & 100
\end{tabular}

Dari tabel diatas dapat dijelaskan bahwa seluruh responden dengan jenis persalinan normal dan sebagian besar tidak mengalami postpartum blues yaitu sebanyak 21 responden $(70 \%)$.

6. Status Kehamilan dengan Kejadian Postpatum Blues

Tabel 13 : Hubungan Status Kehamilan dengan Postpartum Blues Tahun 2018

\begin{tabular}{lcccccc}
\hline \multirow{2}{*}{$\begin{array}{c}\text { Status } \\
\text { Kehamilan }\end{array}$} & \multicolumn{3}{c}{ Postpartum Blues } & \multicolumn{2}{c}{ Total } \\
\cline { 2 - 6 } & \multicolumn{2}{c}{ Iya } & \multicolumn{3}{c}{ Tidak } & \\
\cline { 2 - 6 } & $\mathrm{n}$ & $\%$ & $\mathrm{n}$ & $\%$ & $\mathrm{n}$ & $\%$ \\
\hline Direncanakan & 9 & 30 & 21 & 70 & 30 & 100 \\
\hline Total & 9 & 30 & 21 & 70 & 30 & 100
\end{tabular}

Dari tabel diatas dapat dijelaskan bahwa seluruh responden dengan status kehamilan yang direncanakan dan sebagian besar tidak mengalami postpartum blues yaitu sebanyak 21 responden $(70 \%)$.

\begin{tabular}{lcccccc}
\hline \multirow{2}{*}{$\begin{array}{l}\text { Status } \\
\text { Pernikahan }\end{array}$} & \multicolumn{3}{c}{ Postpartum Blues } & \multicolumn{2}{c}{ Total } \\
\cline { 2 - 6 } & \multicolumn{2}{c}{ Iya } & \multicolumn{3}{c}{ Tidak } & \\
\cline { 2 - 6 } & $\mathrm{n}$ & $\%$ & $\mathrm{n}$ & $\%$ & $\mathrm{n}$ & $\%$ \\
\hline Sah & 9 & 30 & 21 & 70 & 30 & 100 \\
\hline Total & 9 & 30 & 21 & 70 & 30 & 100 \\
\hline
\end{tabular}

Dari tabel diatas dapat dijelaskan bahwa seluruh responden dengan status pernikahan sah dan sebagian besar tidak mengalami postpartum blues yaitu sebanyak 21 responden (70\%).

\section{PEMBAHASAN}

1. Mengindentifikasi Umur Pada Kejadian Postpartum Blues

Hasil penelitian didapatkan bahwa postpartum blues sebagian besar terjadi pada rentang umur 20 35 tahun yaitu sebanyak 9 responden $(30 \%)$ dengan nilai $p$ value $=0,04$ $(<0,05)$ yang berati ada hubungan umur dengan kejadian postpartum blues

Usia dalam persalinan dan melahirkan seringkali dikaitkan dengan masalah postpartum blues. Usia yang terlalu muda untuk hamil akan memicu resiko bagi ibu dan anak dari segi fisik dan psikis baik itu selama kehamilan maupun persalinan (Rusli, 2011). Faktor pencetus terjadinya postpartum blues adalah pada usia remaja atau kurang dari 20 tahun (Bobak, 2005). Hal ini sesuai dengan data BKKBN (2012) yang menyatakan bahwa usia ideal wanita untuk hamil dan melahirkan adalah pada rentang usia 20-35 tahun.

Kejadianpostpartum blues sebagian besarterjadi pada responden dengan umur 20 - 35 tahun. Penelitian ini pun sejalan dengan penelitian yang dilakukan Ibrahim, dkk (2012) 
menunjukkan bahwa responden yang paling banyak mengalami depresi sebagian besar responden dengan kelompok umur 25-29 tahun sebanyak $40,8 \%$. Hal tersebut dikarenaka untuk usia pernikahan sudah diatur oleh BKKBN, undang - undang pernikahan, dan telah banyaknya sosialisasi tentang usia pernikahan ideal, maka sudah banyak ibu - ibu yang hamil dengan usia ideal yaitu 20 -35 tahuan. Berkaitan dengan adanya postpartum blues pada umur 20 - 35 tahun dimana seorang wanita msih produktif baik dalam masalah yang berkaitan dnegan kebutuhan fisik dan berperan aktif daam keluarga. Dengan adanya peran yang melekat tersebut dapa memicu seorang ibu untuk mengalami postpartum blues.

2. Mengindentifikasi Pendidikan Pada Kejadian Postpartum Blues

Hasil penelitian dapatdijelaskan bahwa postpartum blues sebagian besar terjadi pada tingkat pendidikan SMP yaitu sebanyak 7 responden $(23,3 \%)$ dengan nilai $p$ value $=0,049(<0,05)$ yang berati ada hubungan pendidikan dengan kejadian postpartum blues.

Pendidikan ibu yang rendah dapat mempengaruhi adanya kejadian postpartum. Pada ibu yang memiliki pendidikan rendah akan cenderung mempunyai banyak anak dan tehnik dalam perawatan bayi pun kurang baik (Machmudah, 2010). Selain itu hal ini juga dinyatakan oleh penelitian Manurung, (2011) bahwa ibu yang berpendidikan SD/SMP akan berpeluang mengalami postpartum bluessebesar empat kali dibanding ibu yang berpendidikan SLTA atau Diploma I.

Pendidikan berpengaruh secara tidak langsung terhadap kejadian postpartum blues karena pendidikan berpengaruh terhadap pola pikir seseorang. Pola pikir seseorang tersebut akan mempengaruhi koping stres. Selain itu dengan pendidikan tinggi memungkinkan lebih banyak pengalaman dan wawasan dibandingkan dengan seseorang dengan pendidikan rendah sehingga lebih dapat mengelola masalah yang dihadapai dan terhindar dari maslah - masalah psikologis yang salah satunya postpartum blues

\section{Mengindentifikasi Pekerjaan Pada Kejadian Postpartum Blues}

Hasil penelitian dapat dijelaskan bahwa postpartum blues sebagian besar terjadi pada ibu yang tidak bekerja yaitu sebanyak 5 responden (16,7\%) dengan nilai $p$ value $=0,156(>0,05)$ yang berati tidak ada hubungan pekerjaan dengan kejadian postpartum blues.

Wanita karir yang sudah matang khususnya, sangat sulit melepaskan sikapnya yang teratur sewaktu merawat bayi. Mereka berfikir dapat menangai, tetapi sewaktu bayi membuatnya kerepotan dengan tangisan yang terus menerus, rasa lapar yang tidak teratur, jadwal yang tiak jelasdan membuatnya kurang tidur, perempuan - perempuan ini umumnya lebih rentan terhadap postpartum blues. Ibu yang mempunyai pendidikan tinggi akanmenghadapi konflik peran dan tekanan sosial antara tuntutan sebagai ibu yang bekerja dan sebagai ibu rumah tangga.

Pada hasil penelitian tidak sesuai dengan teori yang diungkapkan karena pada ibu yang tidak bekerja dia lebih fokus terhadap apa yang terjadi pada diri dan bayinya, sehingga jika terdapat masalah maka seorang ibu tersebut lebih menyalahkan dirinya sehingga lebih rentan terkena postpartum blues. Dan dengan tidak bekerja kurangnya informasi dan wawasan dari teman teman yang nantinya dapat dijadikan pengalaman dalam mengasuh anaknya. 


\section{Mengindentifikasi Status Obstetrik}

Pada Kejadian Postpartum Blues

Hasil penelitian dapat dijelaskan bahwa postpartum blues sebagian besar terjadi pada status obstetrik primipara yaitu sebanyak 6 responden $(20 \%)$ dengan nilai $p$ value $=0,011 \quad(<0,05)$ yang berati ada hubungan status obstetrik dengan kejadian postpartum blues.

Pengalaman selama persalinan, rasa sakit yang luar biasa saat proses kelahiran bisa menjadi faktor pencetus, misalnya pada ibu yang harus di induksi beberapa kali, ketuban pecah sebelum mengalami proses pembukaan, episiotomy yang menimbulkan rasa sakit dan nyeri atau juga persalinan dengan operasi.

Pengalan dalam melahirkan memegang peranan yang penting dalam kejadian postpartum blues. Ibu yang baru melahirkan pertama kali cenderung lebih mengalami postpartum blues dibandingkan dengan ibu yang sudah pernah mengalami persalinan sebelumnya. Ibu yang baru pertama kali melahirkan akan melakukan adaptasi perubahan peran yang belum pernah dilalui sebelumnya sehingga lebih cenderung mengalami postpartum blues. Hal ini sejalan dengan penelitian yang dilakukansebelumnya bahwa sebagian besar responden yang mengalami postpartum blues adalah primipara yaitu 14 responden $(63,6 \%)$. Terdapat hubungan antara paritas dengan kejadian postpartum dengan nilai $\mathrm{p}=0,027$.

5. Mengindentifikasi Jenis Persalinan

Pada Kejadian Postpartum Blues

Hasil penelitian dapat dijelaskan bahwa seluruh responden dengan jenis persalinan normal dan sebagian besar tidak mengalami postpartum blues yaitu sebanyak 21 responden $(70 \%)$.
Jenis prsalinan berhubungan dengan komplikasi yang dialami seorang ibu dalam bersalin. Ibu yang mengalami persalinan dengan tindakan cenderung akanmengalami komplikasi dibandingkan dengan ibu yang bersalin secara normal. Hasil penelitian ini sejalan dengan penelitian sebelumnyabahwa kemungkinan terjadinya depresi postpartum terjadi pada responden yang mengalami persalinan komplikasi sebesar 53,7\% dan sebesar $46,3 \%$ pada responden yang melahirkan normal. Hasil penelitian yang disampaikan Ibrahim, dkk (2012) sebagian besar terdapat pada jenis persalinan patologis (caesaria) sebanyak 14 responden $(46,7 \%)$, sedangkan pada persalinan fisiologis (normal) hanya berjumlah 1 responden $(2,2 \%)$. Hal ini pun sesuai dengan pendapat peneliti lain bahwa penyulit persalinan berhubungan dengan terjadinya postpartumblues.

6. Mengindentifikasi Status Kehamilan Pada Kejadian Postpartum Blues

Dari hasil penelitian dapat dijelaskan bahwa seluruh responden dengan status kehamilan yang direncanakan dan sebagian besar tidak mengalami postpartum blues yaitu sebanyak 21 responden $(70 \%)$.

Status kehamilan yang direncanakan akan menjadikan ibu lebih siap dalam menghadapi persalinan dan menjalankan perannya sebagai seorang ibu. Dengan adanya kesiapan maka ibu akan lebih bisa menerima bayi dan perubahan peran yang terjadi kepadanya, selain itu dengan kehamilan yang direncanakan akan mendukung dukungan dari keluarga juga terkait dengan kehadiran bayi di tengah- tengah kehidupan keluarga. 


\section{SIMPULAN DAN SARAN}

\section{Simpulan}

a. Umur 20 - 35 tahun sebagian besar terjadi postpartum blues, yang berati ada hubungan umur dengan kejadian postpartum blues

b. Tingkat pendidikan SMP sebagian besar terjadi postpartum blues, yang berati ada hubungan pendidikan dengan kejadian postpartum blues

c. Ibu yang tidak bekerja sebagian besar terjadi postpartum blues yang berati tidak ada hubungan pekerjaan dengan kejadian postpartum blues

d. Status obstetrik primipara sebagian besar terjadi postpartum blues, yang berati ada hubungan status obstetrik dengan kejadian postpartum blues

e. Seluruh responden dengan jenis persalinan normal dan sebagian besar tidak mengalami postpartum blues

f. Seluruh responden dengan status kehamilan yang direncanakan dan sebagian besar tidak mengalami postpartum blues

g. Faktor - faktor yang berpengaruh terhadap kejadian postpartum blues meliputi umur, pendidikan, dan status obstetrik

\section{Saran}

a. Bagi BPM

BPM meningkatkan KIE tentang persiapan menjadi ibu sehingga ibu dapat melakukan adaptasi dengan baik pasca persalinan

b. Bagi Ibu

Menambah informasi dengan membaca buku dan menggali informasi - informasi dari berbagai sumber tentang persiapan menjadi ibu

c. Bagi Keluarga
Memberikan dukungan biak secara moril maupun materiil kepada ibu sehigga ibu dapat melewati masa - masa adaptasi menjadi seorang ibu dan tidak terjadi postpartum blues

\section{DAFTAR PUSTAKA}

Afiyanti, Y. 2002. Negotiating Motherhood: The Difficulties and Challenges of Rural First-Time Mothers in Parung, West Java. Makara Kesehatan University of Indonesia, Vol.6 No.2 : 29-34

Ambarwati ER, Wulandari Diah. 2010. Asuhan Kebidanan Nifas. Yogyakarta : Nuha Medika.

Bloch M, Rotenberg N, Koren D, Klein E. 2005. Risk Factors Associated Withthe Developmentof Postpartum Mood Disorder. Journal of Affective Disorders ; 88:9-18

Bobak, Laudermilk, Jensen, et all. 2005. Buku Ajar Keperawatan Maternitas. Jakarta : EGC

Departemen Kesehatan Indonesia. 2005. Panduan Bagi Petugas dan Relawan Kesehatan Mental. Jakarta.

Dewi, R., Mariati, \& Elly, W. 2012. Hubungan Pemberian Asi Pada Bayi Umur <10 Hari Dengan Gejala Postpartum Blues Dikota Bengkulu . Jurnal Buletin Penelitian Sistem Kesehatan, Vol.15 No.2: 193-202

Elvira SD. 2006. Depresi Pasca Persalinan. Balai penerbit FKUI.1-43

Fatimah, S. 2009 . Hubungan Dukungan Suami dengan Kejadian Postpartum Blues pada Ibu Primipara di Ruang Bugenvile RSUD Tugurejo Semarang. Artikel Riset Keperawatan

Gale, S., \& Harlow, B. L. 2003. Postpartum Mood Disorders : A 
Review Of Clinical And Epidemological Factors.

Ibrahim, F., Rahma, \& Ikhsan, M. 2012. Faktor-Faktor yang Berhubungan dengan Depresi Postpartum di RSIA Pertiwi Makasar. Jurnal.

Iskandar, S.S. 2007. Depresi Pasca Kehamilan (Postpartum Blues). http://www.mitrakeluarga.net/depr esikehamilan.html. diakses tanggal 11 Desember 2017. Journal of Psychosomatic Obstetrics and Gynecology

Klainin P,Arthur D.G. 2009. Postpartum Depressionin Asian Cultures: A literature review. International Journal of Nursing Studies :135573

Latifah, L., \& Hartati. 2006. Efektifitas Skala Endinburgh dan Skala Beck dalam endeteksi Risiko Depresi Postpartum di RSU Prof. DR. Margono Soekarjo Purwokerto. Jurnal Keperawatan Soedirman (The Soedirman Juenal Nursing), Vol 1, No 1: 15-19

Machmudah. 2010. Pengaruh Persalinan dengan Komplikasi Terhadap Kemungkinan Terjadinya Pospartum Blues di Kota Semarang. Tesis Keperawatan Universitas Indonesia.

Manurung, S., Lestari, T. R., Suryati, B., Mitadwiyana, B., Karma, A., \&
Paulina, K. 2011. Efektivitas Terapi Musik Terhadap Pencegahan Postpartum Blues pada Ibu Primipara di Ruang kebidanan RSUP Cipto Mangunkusumo Jakarta Pusat. Jurnal Buletin Penelitian Sistem Kesehatan. Vol.4 No.1.hlm 17-23

Marmi, dkk. 2011. Asuhan Kebidanan Patologi. Yogyakarta: Pustaka Pelajar

Nirwana Ade B, 2011. Psikologi Ibu Bayi dan Anak. Yogyakarta: Nuha Medika. Penerbit Buku Kedokteran EGC.

Rahmandani, A., Karyono, \& Dewi, E. K. 2008. Strategi Penanggulangan Coping pada Ibu yang Mengalami Postpartum Blues di RSU Daerah Kota Semarang. Journal Psikologi

Rahmawati, dkk. 2009. Perawatan Masa Nifas. Cetakan ke-3. Yogyakarta: Fitramaya.

Rusli, R. A., Meiyuntariningsih, T., \& Warni, W. E. 2011. Perbedaan Depresi Pasca Melahirkan pada Ibu Primipara Ditinjau dari Usia Ibu Hamil. Jurnal INSAN. Vol 13, No 01: 21-31.

Urbayatun, S. 2010. Dukungan Sosial dan Kecenderungan Depresi Postpartum pada Ibu Primipara di Derah Gempa Bantul. Humanitas, Vol.VII No.2: 114-122 